\title{
Undergraduate EFL Students' Perception towards the Use of Mendeley Referencing System on Students' Thesis Writing
}

\author{
Made Hery Santosa ${ }^{1}$, Luh Diah Surya Adnyani ${ }^{2}$ Luh Rika Amarwati ${ }^{*}$
}

1,2,3 English Language Education Study Program, Ganesha University of Education, Singaraja, Indonesia

\section{A R T I C L E I N F O}

Article history:

Received March 04, 2021

Revised March 05, 2021

Accepted April 24, 2021

Available online May 25, 2021

\section{Kata Kunci :}

Undergraduate Students, Mendeley, Perception, Thesis Writing

Keywords:

Mahasiswa, Mendeley, Persepsi, Penulisan Skripsi

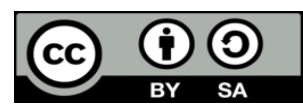

This is an open access article under the $\underline{C C}$ BY-SA license.

Copyright (C) 2021 by Author. Published by Universitas Pendidikan Ganesha

\begin{abstract}
A B S T R A K
Managing citations and references in academic writing context is highly important. Nowadays, the development of technology is highly exploded, and it can help and manage human's work. One of the tools that have been suggested by many experts regarding managing citation and references is an automation based tool. Many automation tools can be used for students to manage citations and references, such as Ms. Word References, Reworks, Zotero, Endnote, Mendeley, etc. This study aimed at investigating undergraduate students' perception towards the use of Mendeley referencing system on students' thesis writing and describe challenges faced by undergraduate students when using Mendeley on thesis writing. This study used mixed-method research design, particularly explanatory sequential mixed-method. 100 undergraduate students of English Language Education. The instruments used in this study are questionnaire and interview. Questionnaire consisted of 16 statements and interview consisted of 12 questions. The result of questionnaire showed very positive perception which means the students strongly agreed that Mendeley usage on students' thesis writing is highly useful. Moreover, the interview result showed the challenges came up when the students connecting Mendeley to Ms. Word and the Metadata of articles and books could not generated automatically. Thus, the students need to re-check and input the Metadata manually. However, the students stated they overcame the challenge by watching tutorials from YouTube and reading articles from the internet. Besides that, the students also mentioned the challenge also appeared since not all articles could be generated automatically. Sometimes, the students need to input and re-check manually the data of articles such as the title, author's name, pages, year, etc. It means that the students need to spend a bit a long time managing citations and references on their thesis.
\end{abstract}

\section{A B S T R A C T}

Mengelola kutipan dan referensi dalam konteks penulisan akademik sangat penting. Saat ini perkembangan teknologi sangat pesat, dapat membantu dan mengatur pekerjaan manusia. Salah satu alat yang telah disarankan oleh banyak ahli mengenai pengelolaan kutipan dan referensi adalah alat berbasis otomatisasi. Banyak alat otomatisasi yang dapat digunakan mahasiswa untuk mengelola kutipan dan referensi, seperti Ms. Word References, Reworks, Zotero, Endnote, Mendeley, dll. penulisan tesis dan mendeskripsikan tantangan yang dihadapi oleh mahasiswa saat menggunakan Mendeley pada penulisan tesis. Penelitian ini menggunakan desain penelitian mixed-method, khususnya explanatory sequential mixed-method. 100 mahasiswa S1 Pendidikan Bahasa Inggris. Instrumen yang digunakan dalam penelitian ini adalah angket dan wawancara. Kuesioner terdiri dari 16 pernyataan dan wawancara terdiri dari 12 pertanyaan. Hasil angket menunjukkan persepsi yang sangat positif yang artinya mahasiswa sangat setuju bahwa penggunaan Mendeley dalam penulisan skripsi mahasiswa sangat bermanfaat. Selain itu, hasil wawancara menunjukkan tantangan muncul ketika siswa menghubungkan Mendeley ke Ms. Word dan Metadata artikel dan buku tidak dapat dihasilkan secara otomatis. Oleh karena itu, siswa perlu mengecek ulang dan menginput Metadata secara manual. Namun, para siswa menyatakan bahwa mereka mengatasi tantangan tersebut dengan menonton tutorial dari YouTube dan membaca artikel dari internet. Selain itu, para mahasiswa juga menyebutkan tantangan juga muncul karena tidak semua artikel bisa dihasilkan secara otomatis. Terkadang mahasiswa perlu menginput dan mengecek ulang secara manual data-data artikel seperti judul, nama penulis, halaman, tahun, dll. Artinya mahasiswa perlu meluangkan sedikit waktu untuk mengelola kutipan dan referensi pada skripsinya.

\section{INTRODUCTION}

Managing citations and references in academic writing context is highly important. Students are required to know the citation style they used in their writing to prevent plagiarism (Santosa et al., 2020). Surprisingly, there are several problems that EFL students faced, which are: 1) one of the common problems that students face is managing citation and references in the list of their writing (Ariyanti \& Fitriana, 2020). 
It is stated that students tend to use various sources to support their writing, such as books, articles, journals, etc. Moreover, they are required to paraphrase the ideas, add the citation and references to prevent plagiarism. Nevertheless, surprisingly, some students still lack knowledge in managing citations and references. So, they prefer to use a manual way, which can influence their thesis quality. 2) some students still use manual ways in managing citations and references (Ariyanti \& Fitriana, 2020). Using a manual way of managing citations and references is risky. The possibility that this might happen, the students will forget to add citations and references in their writing, and plagiarism will currently appear (Ariyanti \& Fitriana, 2020). Besides, when the students use the manual way, it enlarges students' possibility to write citations and references incorrectly and inconsistently. 3) EFL students lack knowledge of the citation style that must be used and appropriate to their learning context (Santosa et al., 2020). However, EFL students still do not understand which one is APA style, MLA, Oxford, etc. However, working on a thesis is a challenging job that must be done for university students. It can be avoided that citing and referencing the sources is highly important in writing to prevent plagiarism (Santosa et al., 2020). So, EFL students have to be wiser to overcome the challenges.

Nowadays, the development of technology is highly exploded, and it can help and manage human's work. One of the tools that have been suggested by many experts regarding managing citation and references is an automation based tool. Many automation tools can be used for students to manage citations and references, such as Ms. Word References, RefWorks, Zotero, Endnote, Mendeley, etc. Mendeley is one of the reference management software that has been suggested for students, especially in writing. Numerous experts stated that Mendeley is highly recommended to use due to the provided efficiency and flexibility. However, the researcher conducted a preliminary study at the Ganesha University of Education, especially English Language Education students. The purpose of conducting the preliminary study are 1) To know the number of ELE students use Mendeley as automation based tools on students' thesis. 2) To know what kind of tools that students use before use Mendeley. 3) Does ELE lecturers suggest you to use Mendeley in writing?. The survey was spread out to ELE students, and after five days, 64 respondents answered the survey. The survey results showed that $64 \%$ of students stated that they use Mendeley in thesis writing, and 36\% stated they do not use Mendeley. Regarding to the tools that students use before use Mendeley, it was found that $85 \%$ students use Ms. Word Reference and 15\% use manual way. Moreover, 97\% stated that ELE lecturers suggest them to use Mendeley in writing and 3\% of them stated ELE lecturers contrastly. However, it can conclude that most ELE students use Mendeley on thesis writing. In addition, before the students use Mendeley they use Ms. Word Reference and manual way to manage citations and references on their thesis. And most of ELE lecturers suggest the students to use Mendeley in writing Nevertheless, surprisingly, there is no research investigating students' perception of Mendeley usage in English Language Education, Ganesha University of Education. Moreover, describe challenges faced by students in using Mendeley on thesis writing.

Moreover, some previous studies incorporating Mendeley's use in academic writing had been conducted by some researchers have found that students had positive perception towards the use of Mendeley since Mendeley can be used to support the students in managing citations and references of their writing (Ariyanti \& Fitriana, 2020; Iskandar \& Patak, 2019; A. A. Patak \& Tahir, 2019; Andi Anto Patak et al., 2016). Based on the previous researches above, the novelty of this research is since research on this topic involves undergraduate EFL students in North Bali is still limited and scarce, this research aimed to contribute as reading material to this area. Research investigating the perception of undergraduate EFL students on Mendeley's use of thesis writing is a new one, primarily conducted at a University located in North Bali. Looking at the fact that many ELE students use Mendeley on their thesis writing, there is no research investigating the perception of undergraduate EFL students towards the use of Mendeley on students' thesis. Therefore, it is crucial to conduct this research to discover the reflection of Mendeley's usage in thesis writing. Moreover, it will provide information showing challenges perceived by undergraduate EFL students towards Mendeley usage on the thesis writing context.

\section{METHODS}

This research is designed in the form of a mixed-method research design. A mixed-method research design involves and combines two data in the forms of quantitative and qualitative data (Creswell, 2014). The type of mixed-method design that used in this research is explanatory sequential mixed-method. An explanatory sequential mixed method is a part of a mixed-method design that collects data in the form of quantitative at the first phase and then continued by collecting data in the form of qualitative at the second phase (Creswell, 2014). However, in this design, the quantitative data was done at the first phase, and it will continue to qualitative data collection, which will explain the result in the first phase (Creswell, 
2014). The flowchart of mixed-method design, explanatory sequential mixed-method can be shown as Figure 1.

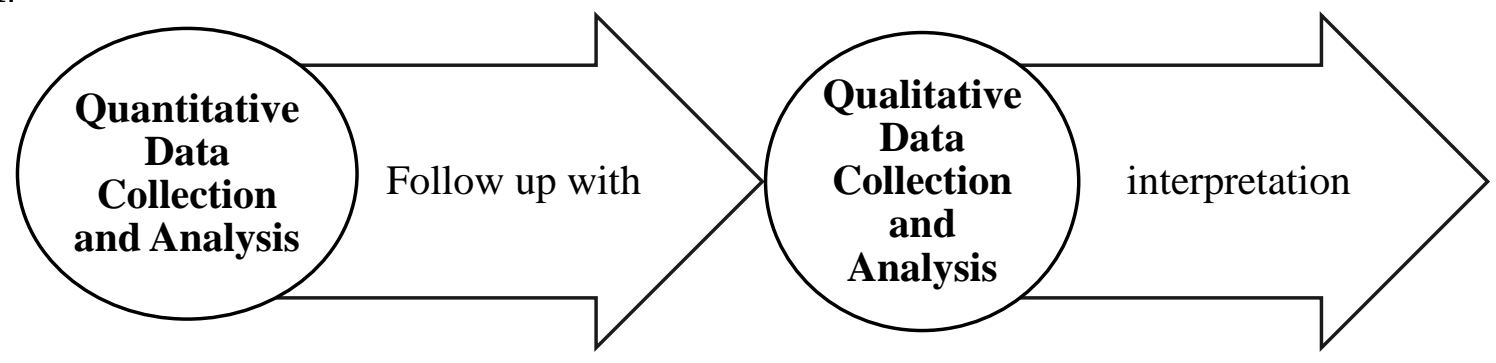

Figure 1. Explanatory Sequential Mixed-Method Creswell (2012)

The Subject of this research is undergraduate EFL students, especially English Language Education students. However, this research uses purposive sampling, which means that a particular group was chosen as a representative of the research population (Ary et al., 2009). There are several criteria sample of this study such as: 1) The sample must be undergraduate EFL students, English Language of Education students who working on thesis writing. 2) The students are used Mendeley on their thesis. From those two criteria, there were $100 \mathrm{EFL}$ students who come from $7^{\text {th }}, 9^{\text {th }}, 11^{\text {th }}, 13^{\text {th }}$ semester students of English Language Education students, Ganesha University of Education involved in this study. In this study, the data of EFL students' perception on the use of Mendeley were collected using two instruments, namely questionnaire and interview guide. The questionnaire and interview guide consisted of three dimensions namely, perceiver, target, and situation. However, the instruments were adapted based on adapted model (Bicen \& Kocakoyun, 2018; Buzzetto-more, 2008; Neill \& Russell, 2019; Andi Anto Patak et al., 2016; Rosida, 2018). The questionnaire consisted of 16 valid statements and the interview guide consisted of 12 valid questions.

Before collecting the data, the questionnaire was measured in terms of content validity, empirical validity, and reliability. In content validity, the questionnaire was measured by two expert judges and it found there was no invalid item of questionnaire. After content validity, empirical validity was conducted by trying out the questionnaire and it was found 2 of 18 invalid items. Besides, the reliability of questionnaire was measured using Cronbanch's Alpha and it was found that the instrument was reliable since the score was 0.888 . The interview guide as the second instrument was also measured in terms of content validity and judged by two experts. The result of content validity of the interview guide showed 12 items of questions were valid. The data of undergraduate EFL students' perception towards the use of Mendeley on students' thesis were collected by distributing questionnaire and the result of the questionnaire were used as base to design interview guide. Therefore, the interview guide was used to find the challenges faced by EFL students in using Mendeley on thesis writing context. However, the data of questionnaire analyzed using mean score and frequency from each dimension. Meanwhile, the interview result analyzed using an interactive model such as data collection, data reduction, data display, and conclusion (drawing /verifying) (Milles \& Huberman, 1992).

\section{RESULT AND DISCUSSION}

\section{Results}

\section{Undergraduate EFL Students' Perception on Mendeley Usage}

The results of the questionnaire were analyzed on the first phase. The mean score was 66.42 . The categorization of the score is shown in Table 1:

Table 1. The Categorization of Mean Score of Undergraduate EFL Students' Perception towards the Use of Mendeley on Students' Thesis

\begin{tabular}{ccccc}
\hline No. & Criteria & Interval & Categorization & Qualification \\
\hline 1. & $\mathrm{MI}+1.5 \mathrm{SDI}<\mathrm{M}<\mathrm{Mi}+3.0 \mathrm{SDi}$ & $64<\mathrm{M}<80$ & Very high & Very positive \\
2. & $\mathrm{MI}+0.5 \mathrm{SDI}<\mathrm{M}<\mathrm{MI}+1.5 \mathrm{SDI}$ & $53<\mathrm{M}<64$ & High & Positive \\
3. & $\mathrm{MI}-0.5 \mathrm{SDI}<\mathrm{M}<\mathrm{MI}+0.5 \mathrm{SDI}$ & $43<\mathrm{M}<53$ & Average & Neutral \\
4. & $\mathrm{MI}-1.5 \mathrm{SDI}<\mathrm{M}<\mathrm{MI}-0.5 \mathrm{SDI}$ & $32<\mathrm{M}<43$ & Low & Negative \\
5. & $\mathrm{MI}-3.0 \mathrm{SDI}<\mathrm{X}<\mathrm{MI}-1.5 \mathrm{SDI}$ & $16<\mathrm{M}<32$ & Very low & Very negative \\
\hline
\end{tabular}

The mean score was 66.42 and it was in interval $64<\mathrm{M}<80$. So, it can be inferred that undergraduate EFL students in English Language Education, Ganesha University of Education had very positive perception 
towards the use of Mendeley on students' thesis. This means that students very agreed that Mendeley usage was beneficial for students' who working on their thesis writing. Beside the mean score, the frequency of each dimension were analyzed. There are three dimensions used in this study namely, perceiver, target, and situation. After the data completed to analyze, result of frequency of perception on each dimensions were presented in frequency tables. The table consisted of percentage of students' responses on items of questionnaire from each dimension. Table 2 presents the students' perception of perceiver dimension.

Table 2. Students' perception on perceiver dimension

\begin{tabular}{|c|c|c|c|c|c|c|c|c|c|}
\hline \multirow{2}{*}{$\begin{array}{c}\text { Dimension } \\
\text { Percentage } \\
\text { Response }\end{array}$} & \multicolumn{8}{|c|}{ Perceiver (\%) } & \multirow{2}{*}{$\begin{array}{c}\text { Average } \\
(\%)\end{array}$} \\
\hline & S1 & S2 & S3 & S4 & S5 & S6 & S7 & S8 & \\
\hline Strongly Agree & 65 & 63 & 2 & 45 & 52 & 35 & 42 & 32 & 42.0 \\
\hline Agree & 26 & 29 & 15 & 42 & 41 & 37 & 44 & 45 & 34.9 \\
\hline Neutral & 5 & 5 & 29 & 7 & 5 & 20 & 11 & 21 & 12.9 \\
\hline Disagree & 4 & 3 & 35 & 6 & 2 & 8 & 3 & 2 & 7.9 \\
\hline Strongly Disagree & 0 & 0 & 19 & 0 & 0 & 0 & 0 & 0 & 2.4 \\
\hline Total & 100 & 100 & 100 & 100 & 100 & 100 & 100 & 100 & 100 \\
\hline
\end{tabular}

Table 2 shows the results of the questionnaire analysis on students' perception about the perceiver dimension of Mendeley usage on students' thesis writing. It was found that $42.0 \%$ students responded strongly agree, $34.9 \%$ responded agree, $12.9 \%$ responded neutral, $7.9 \%$ responded disagree, and $2.4 \%$ responded strongly disagree. Therefore, it can be inferred that students' perception about perceiver dimension that $76.9 \%$ students had positive perception, $12.9 \%$ students had neutral perception, and $10.3 \%$ students had negative perception. This means that undergraduate EFL students of English Language Education, Ganesha University of Education had very positive perception towards the use of Mendeley on their thesis writing.

Table 3. Students' perception of target dimension

\begin{tabular}{ccccccc}
\hline Dimension & \multicolumn{3}{c}{ Target (\%) } & \multicolumn{2}{c}{$\begin{array}{c}\text { Average } \\
\text { (\%) }\end{array}$} \\
$\begin{array}{c}\text { Percentage } \\
\text { Response }\end{array}$ & $\mathbf{S 9}$ & $\mathbf{S 1 0}$ & $\mathbf{S 1 1}$ & $\mathbf{S 1 2}$ & $\mathbf{S 1 3}$ & 39.2 \\
\hline Strongly Agree & 26 & 40 & 42 & 40 & 48 & 37.8 \\
Agree & 48 & 33 & 36 & 38 & 34 & 17.4 \\
Neutral & 24 & 18 & 18 & 12 & 15 & 4.6 \\
Disagree & 2 & 5 & 3 & 0 & 0 & 1.0 \\
Strongly Disagree & 0 & 4 & 1 & $\mathbf{1 0 0}$ & $\mathbf{1 0 0}$ & $\mathbf{1 0 0}$ \\
\hline Total & $\mathbf{1 0 0}$ & $\mathbf{1 0 0}$ & $\mathbf{1 0 0}$ & $\mathbf{1 0 0}$
\end{tabular}

Table 3 shows that $39.2 \%$ students responded strongly agree, 37.8\% students responded agree, $17.4 \%$ students responded neutral, $4.6 \%$ responded disagree, and $1.0 \%$ responded strongly disagree. Regarding target dimension towards Mendeley usage on thesis writing, $77 \%$ students had positive perception, $17.4 \%$ students had neutral perception, and 5.6\% students had negative perception. The result means that there is a fairly high number of respondents who perceived that Mendeley and its features were beneficial for students especially on students' thesis. The next dimension is the students' perception of situation dimension. Table 4 provides the participants' responses.

Table 4. Students' perception on Situation Dimension

\begin{tabular}{ccccc}
\hline Dimension & \multicolumn{3}{c}{ Situation (\%) } & \multirow{2}{*}{ Average (\%) } \\
\cline { 1 - 4 } Percentage Response & $\mathbf{S 1 4}$ & $\mathbf{S 1 5}$ & $\mathbf{S 1 6}$ & \\
\hline Strongly Agree & 33 & 43 & 47 & 41 \\
Agree & 50 & 31 & 39 & 40 \\
Neutral & 8 & 13 & 12 & 11 \\
Disagree & 7 & 9 & 2 & 6 \\
Strongly Disagree & 2 & 4 & 0 & $\mathbf{1 0 0}$ \\
\hline Total & $\mathbf{1 0 0}$ & $\mathbf{1 0 0}$ & $\mathbf{1 0 0}$ &
\end{tabular}


Table 4 shows that $41 \%$ students responded strongly agree, $40 \%$ students responded agree, $11 \%$ students responded neutral, 6\% responded disagree, and 2\% responded strongly disagree. Regarding situation dimension towards Mendeley usage on thesis writing, 81\% students had positive perception, $11 \%$ students had neutral perception, and $8 \%$ students had negative perception. The result means that high number of respondents who perceived very positive perception on situation dimension to use Mendeley on thesis writing. Based on data from Table 2, Table 3, and Table 4, three dimensions such as perceiver, target, and situation can be summarized and displayed in Figure 1.

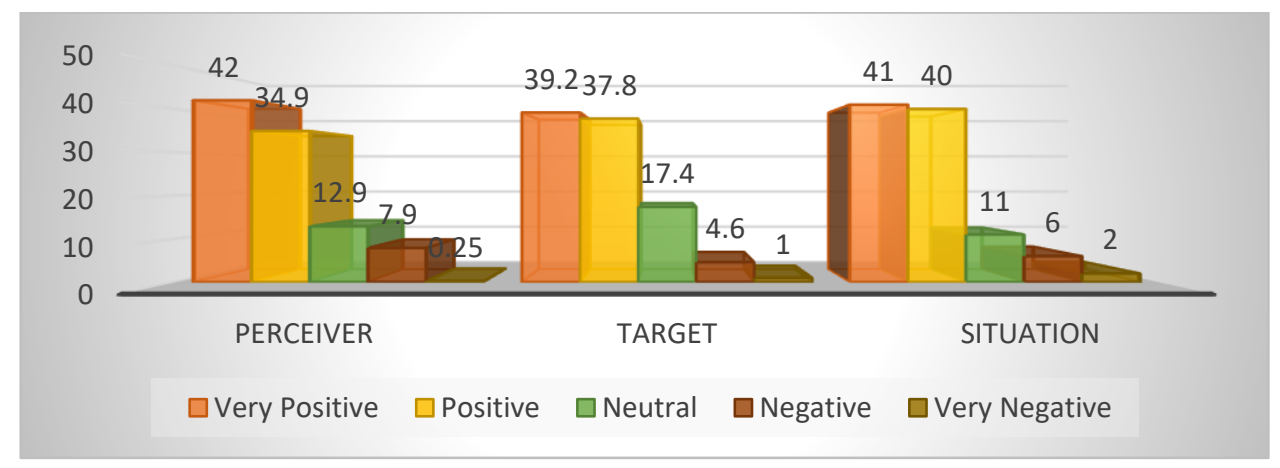

Figure 1. Frequency of Responses for Each Dimension

Figure 1, it can be seen the frequency of distribution undergraduate EFL students' responses towards the use of Mendeley on thesis writing. The first dimension is perceiver, perceiver is an individual who perceive or gives their understanding to the particular thing. Therefore, the perceiver in this study is undergraduate EFL students who give their understanding to Mendeley usage in thesis writing context. The result on this dimension shows that undergraduate EFL students were strongly agree that Mendeley usage brings positive impact on their thesis writing. In addition, 34.9\% responded agree that Mendeley brings positive impact on their thesis writing. $12.9 \%$ students' responded neutral, and $7.9 \%$ responded showed negative perception and it means that undergraduate EFL students disagree that Mendeley usage brings positive impact on their thesis writing. And $2.4 \%$ responded showed very negative perception and it means that the students were very disagree that Mendeley brings positive impact on students' thesis. Since the highest number percentage in perceiver dimension was $42 \%$, it can be inferred that the students had very positive perception and strongly agreed that perceiver dimension or the undergraduate EFL students perceived that the use Mendeley on their thesis writing context was highly useful.

Beside perceiver dimension, the target dimension which defined as the object or particular thing which being or will be interpreted also measured in this study. Therefore, the target of this study was Mendeley which used by undergraduate EFL students on their thesis writing. Based on distribution frequency of responses in target dimension, it can be seen that 39.2\% responded that undergraduate EFL students had very positive perception. The result on this dimension shows that Mendeley and its features made the students interested to use Mendeley. In addition, 37.8\% responded showed positive perception and it means that the students agreed that Mendeley and its features made the students interested to use Mendeley. Therefore, $17.4 \%$ responded neutral, $4.6 \%$ responded showed negative perception or disagreement that Mendeley and its features made the students interested to use Mendeley. And 1\% responded very negative perception or very disagree that Mendeley and its features made the students interested to use Mendeley. Since the highest percentage of responses was 39.2\%, it can be inferred that the students had very positive perception and strongly agree that target dimension or Mendeley usage and its features were highly useful for students who working on thesis writing.

The situation dimension can be defined as circumstances that support individual to perceive something. In this study, time, work setting, and social setting were used as indicators in situation dimension. Therefore, based on Figure 2 it can be seen that $81 \%$ responded shows positive perception on situation dimension. This means that undergraduate EFL students were agree that time, work setting, and social setting as parts of situation dimension were support students to use Mendeley on their thesis writing. $11 \%$ responded showed neutral, and $8 \%$ responded showed negative perception which means that there was disagreement that that time, work setting, and social setting were support students to use Mendeley on their thesis writing. Since the number of positive perception was $81 \%$ which higher than the number of negative perception, it can be inferred that undergraduate EFL students had positive perception on situation dimension and it means the students agreed that it did not need much time to learn how to use 
Mendeley, they use Mendeley on their assignment and their thesis, and the lecturer and their friends as well were influenced the students to use Mendeley on their thesis writing.

Based on the result of questionnaire, it showed that undergraduate EFL students of English Language Education, Ganesha University of Education had positive perception towards Mendeley usage on students' thesis. In addition, three dimensions that used in this study such as perceiver, target, and situation showed high percentage responded which means that the students also had positive perception on those three dimensions. Therefore, the result means that undergraduate EFL students were strongly agree that the use of Mendeley brings positive impacts and beneficial for students' thesis. However, in order to support the questionnaire result, the interview was conducted to get the data and deeply responses whether the result of questionnaire parallel with the result of interview guide or not. Based on the result of the interview, it was found that the challenges came up when the students use Mendeley for the first time, and they were a bit confused about how to connect Mendeley to Ms. Word because there is no direction in Mendeley. Besides, the students also mentioned that not all articles could be generated automatically. Sometimes, the students need to input and re-check manually the data of articles such as the title, author's name, pages, year, and others supporting data. It means that the students need a bit longer time to re-check and input the data in order to create the citations and references on thesis.

\section{Discussion}

\section{EFL Students' Perception towards the use of Mendeley}

The first aspect discussed in this research is undergraduate EFL students' perception of Mendeley's use on students' thesis. The mean score of the perception questionnaire showed that the mean score was in the categorization of very high since the mean score was 66.42 and it was in the interval $64<\mathrm{M}<80$. In other words, it can be inferred that undergraduate EFL students in English Language Education, Ganesha University of Education, had a very positive perception towards the use of Mendeley on students' thesis. This means that students strongly agreed that Mendeley usage is beneficial for students working on their thesis writing. Besides, three dimensions used in this study, such as perceiver, target, and situation, showed a high percentage of respondents, which means that the students also had a positive perception of those three dimensions. Regarding the results of a questionnaire on perceiver dimension was very positive, it seems that undergraduate EFL students of English Language Education strongly agreed that Mendeley usage was beneficial on their thesis writing due to several advantages that the students get such as the students able to cite faster by using Mendeley than using manual citation. The results of this research were supported by previous study who stated that the students attempt to use Mendeley as a reference manager in their thesis writing (Ariyanti \& Fitriana, 2020). They had a positive perception of Mendeley's use since they can easily generate citations and references automatically in a short time and well-managed, and students' ability in recognizing good sources to support their thesis well improve.

In the next item of perceiver dimension, it was found that Mendeley helps the students' understanding about how to manage citation and references of thesis writing properly. They are interested in using Mendeley on their thesis writing, and using Mendeley make the students feel more confident in managing citation and references of my thesis. This is related to after the students used Mendeley on their academic writing, they were impressed with the accuracy of citations and the list of references produced by Mendeley (A. A. Patak \& Tahir, 2019). Mendeley provides ease for their users because the metadata to produce citations and references automatically identified and allowed the users to edit the citations and references. Therefore, the students were decided to leave their bad habit of making citations and references by typing it manually. The students could also generate citations and references in few clicks (Gibson et al., 2012; Neill \& Russell, 2019). Further, the students considered that Mendeley made the students more confident because it effectively maintained citations and references of their writing in a very short time.

Besides the perceiver dimension, the target dimension in this research showed very positive perception. It means that undergraduate EFL students strongly agreed that Mendeley's features are very useful for the students. This is supported by interview results that stated EFL students often use Mendeley to manage the citation and references of their writing, save articles and books which support students' thesis, adding notes to parts that the students did not understand, and highlight important information that supports their thesis. These findings are related to research who stated that Mendeley provides several beneficial features that could be utilized, such as feature backup files, which can be used by the users to back up their files (Bicen \& Kocakoyun, 2018; Buzzetto-more, 2008; Dwihandini et al., 2013). So, the students can find the files easily without any worries. Mendeley also provides annotate features to add important notes and highlights that can be used to highlight important information. Besides that, Mendeley also provides a social network feature that can help the users connect their Mendeley Web and mobile and find any communities related to the area of interest. 
The next finding found that downloading and installing Mendeley's process was easy, quick, and simple. The students stated that as long as they have a good internet connection, the downloading process will be done quickly. Therefore, the students also added that they found many tutorials on YouTube about downloading and installing Mendeley on their personal computers. So, it was not a big problem for the students both to download and install Mendeley. In the next item of the questionnaire on the target dimension, the researcher found several interesting findings. Some feedback from supervisors about incorrect and inconsistent citation style on students' thesis was one reason the students to use Mendeley in managing citations and references of their thesis. These findings are supported by the interview result. There are some students at the beginning of the thesis proposal. They were not used Mendeley yet in managing citations and references of their writing. Sometimes, they type the citations manually and it made the citation they wrote was inconsistent and inaccurate. Besides, some students said that sometimes they forget to edit the citation produced by Mendeley. For the example, the citation result from Mendeley is (Emanuel, 2013; Francese, 2010). When the students want to put the citation in front of the sentence, they need to edit the citation into (Gibson et al., 2012; Iskandar \& Patak, 2019). There were several times that they forgot to edit and got some comments from their supervisors. These findings are interesting because there are no supporting theories that mentioned that supervisors' feedback made the students try to use automation-based tools such as Mendeley to manage the citations and references of their thesis. The interview results also support this; the students stated that since they used Mendeley on their thesis, their supervisors did not give any comments regarding the citation style and references of their writings. The finding of this research showed that the students mentioned Mendeley is similar to Ms. Word Reference as a tool to manage the citations and references. However, Mendeley provides more advantages, such as the citations and references automatically done quickly. Besides, Mendeley also provides several features that could not be found in Ms. Word Reference, such as finding articles, annotating and highlighting, import/add files, etc. Ms. Word reference is a reference manager that could be utilized to manage citations and references, but it cumbersome, especially for big projects because there are no features that could be used to import files and the users need to type the data in making citation and references manually (Iwai, 2011; Khwaja \& Eddy, 2015).

The result of the questionnaire and interview from the situation dimension showed a very positive perception. Therefore, it means that undergraduate EFL students agreed that they did not need much time to learn how to use Mendeley. They always use Mendeley on their assignments and thesis. The lecturers and their friends as well support the students to use Mendeley on their thesis writing. These findings are supported by the interview results that described the students only took less than one hour to learn how to use Mendeley. Besides, some students stated they already know and use Mendeleys since they were in the 4th semester. The scientific writing lecturers were supported and recommended that the students use automation-based tools such as Mendeley. Besides, students' supervisors also recommended the students to use Mendeley on their thesis to create an appropriate and consistent citation style. Since the lecturer and the students' supervisors recommend Mendeley, the students think it is necessary to use Mendeley in managing citations and references of their thesis writing. The students download and install Mendeley on their personal computers, and they watched some tutorials about how to use Mendeley on YouTube.

\section{EFL Students' Challenges on The Use of Mendeley}

The questionnaire result showed that undergraduate EFL students think that they did not feel a high degree of obstacles when using Mendeley. Nevertheless, the students mentioned that there are two challenges that students faced when using Mendeley. This is supported by the interview result, which described that the challenges came up when the students use Mendeley for the first time. They were a bit confused about connecting Mendeley to Ms. Word because there is no direction in Mendeley. The students stated they overcame the challenge by watching tutorials from YouTube and reading articles from the internet. Besides that, the students also mentioned the challenges also appeared since not all articles could be generated automatically. Sometimes, the students need to input and re-check manually the data of articles such as the title, author's name, pages, year, etc. It means that the students need to spend a bit a long time managing citations and references on their thesis. However, overall, EFL students said they like to use Mendeley, they never have bad experiences while using Mendeley such as computer error, lost files, the annotation, and highlight could not be seen, etc. and the students also said that they think their computer's specification supports them to use Mendeley.

However, these findings are slightly different from an aspect that students faced difficulties in citing and writing references in their thesis writing due to students' computer specification, which not support to use of Mendeley. It made some students still use manual way in managing the citations and references of their thesis. Besides, different findings were also found in a study who mentioned that the students faced difficulties using Mendeley both online and desktop versions (Khwaja \& Eddy, 2015; Kosasih, 
2018; Neill \& Russell, 2019). It was also stated that the annotation could not be seen by the other people when they share their articles. Besides, the students also mentioned that they need ongoing training throughout the semester to use Mendeley effectively. However, the different aspects found in a study by might have happened due to the different times of the research being conducted. Mendeley might have several program developments and improvements, making the undergraduate EFL students never have bad experiences while using Mendeley (Ariyanti \& Fitriana, 2020; Khwaja \& Eddy, 2015).

\section{CONCLUSION}

Undergraduate students' perception towards the use of Mendeley referencing system on students' thesis is categorized into very positive perception. It means that the students strongly agree that Mendeley is beneficial for students' thesis. Three dimensions used in this research also showed very positive perception. It means that, the students like, interested and feel that Mendeley is highly useful for students' thesis writing, the Mendeley's features are beneficial and easy to use, and the lecturers are support the students to use Mendeley especially in thesis writing context. In addition, it was also found that students' challenges when using Mendeley came up when the students use Mendeley for the first time, and they were a bit confused about how to connect Mendeley to Ms. Word because there is no direction in Mendeley. However, the students stated they overcame the challenge by watching tutorials from YouTube and reading articles from the internet. Besides that, the students also mentioned the challenge also appeared since not all articles could be generated automatically. Sometimes, the students need to input and re-check manually the data of articles such as the title, author's name, pages, year, etc. It means that the students need to spend a bit a long time managing citations and references on their thesis.

\section{REFERENCES}

Ariyanti, \& Fitriana, R. (2020). EFL Students Perception on Mendeley Reference Manager in Thesis Writing. International Conference on Business, Law, and Pedagogy. https://doi.org/10.4108/eai.16-102019.163223.

Ary, D., Jacobs, L. C., Sorensen, C., \& Razaveieh, A. (2009). Introduction to Research in Education. Wadsworth.

Basak, S. K. (2014). Reference Management Software : Comparative Analysis of RefWorks and Zotero. International Journal of Humanities and Social Sciences, 8(11), 1987-1990. https://doi.org/doi.org/10.5281/zenodo.1096757.

Bicen, H., \& Kocakoyun, S. (2018). Perceptions of Students for Gamification Approach : Kahoot as a Case Study. 72-93. https://doi.org/https://doi.org/10.3991/ijet.v13i02.7467.

Buzzetto-more, N. A. (2008). Student Perceptions of Various E-Learning Components. Interdisplinary Journal of E-Learning and Learning Objects, 4, 113-134. https://doi.org/10.28945/370.

Creswell, J. . (2012). Educational Research Planning, Conducting, and Evaluating Quantitative and Qualitative Research (4th ed.). Pearson Education.

Creswell, J. . (2014). Research Design Qualitative, Quantitative, and Mixed Methods Approaches (4th ed.). Sage Publication.

Dwihandini, L. A., , Marhaeni, A. A. I. N., \& , Suarnajaya, I. W. (2013). The Analysis of The Factors Affecting Undergraduate Students' Difficulties in Writing Thesis in The English Department of Mahasaraswati University. E-Journal Program Pascasarjana Universitas Pendidikan Ganesha, 2, 112.

Emanuel, J. (2013). Users and citation management tools: use and support. 41, 639-659. https://doi.org/10.1108/RSR-02-2013-0007.

Francese, E. (2010). The Usage of Reference Management Software (RMS) in an Academic Environment: A Survey at Tallinn University. International Conference on Integrated Information, 293-296. https://doi.org/http://hdl.handle.net/10760/16975.

George, J. M., \& Jones, G. R. (2005). Understanding and Managing Organizational Behavior (6th editio). Prentice Hall.

Gibson, J. L., Ivancevich, J. M., Donnelly, Jr, J. H., \& Konopaske, R. (2012). Organizations behaviour, structure, processes (14th ed.). McGraw-Hill.

Iskandar, \& Patak, A. A. (2019). The significance of Mendeley usage on the accuracy of citation and references. International Journal of Humanities and Innovation, 2, 108-114. https://doi.org/10.33750/ijhi.v2i4.51.

Iwai, Y. (2011). The Effects of Metacognitive Reading Strategies: Pedagogical Implications for EFL / ESL Teachers. 11(2), 150-159. 
Khwaja, T., \& Eddy, P. L. (2015). Using Mendeley to Support Collaborative Learning in The Classroom. IManager's Journal of Educational Technology, 12(2), 19-28.

Kosasih. (2018). A Genre Analysis of Thesis Abstracts at a State University in Banten. Lingua Cultura, February, 9-14. https://doi.org/10.21512/lc.v12i1.1963.

Miles, M. B., \& Huberman, A. M. (1994). Matthew B. Miles, Michael Huberman - Qualitative Data Analysis_An expanded Sourcebook 2nd Edition (1994).pdf. Sage Publication.

Neill, R. O., \& Russell, A. M. T. (2019). Stop! Grammar time: University students ' perceptions of the automated feedback program Grammarly. Australasian Journal of Education Technology, 35(1), 4256. https://doi.org/10.14742/ajet.3795.

Nurkhin, A., Rustiana, A., Pramusinto, H., \& Setiyani, R. (2019). Is the Use of Reference Managers Driven by Necessity or Policy Pressure? International Conference on Education, Science and Technology, 1-6. https://doi.org/10.1088/1742-6596/1387/1/012108.

Parabhoi, L., Seth, A., \& Pathy, S. (2017). Citation Management Software Tools : a Comparison with Special Reference to Zotero and Mendeley. Journal of Advances in Library and Information Science, 6(JulySeptember), 288-293.

Patak, A. A., Naim, H. A., \& Hidayat, R. (2016). Taking Mendeley as Multimedia-based Application in Academic Writing. International Journal on Advance Science Engineering Information Technology, 6(4), 557-560. https://doi.org/10.18517/ijaseit.6.4.890.

Patak, A. A., \& Tahir, M. (2019). Avoiding plagiarism using Mendeley in Indonesian higher education setting. International Journal of Evaluation and Research In Education, 8(4), 686-692. https://doi.org/10.11591/ijere.v8i4.20268.

Robbin, S. P., \& Judge, T. A. (2013). Organizational Behavior (15th ed.). Pearson Education Limited.

Rosida, N. A. (2018). Students' Attitudes Towards The Use of Zotero As Web-Based Citation Management Tool in Academic Writing at UIN Sunan Ampel Surabaya.

Salija, K., Hidayat, R., \& Patak, A. A. (2016). Mendeley Impact on Scientific Writing: Thematic Analysis Mendeley Impact on Scientific Writing : Thematic Analysis. International Journal on Advance Science Engineering Information Technology, 6(5), 657-662. https://doi.org/10.18517/ijaseit.6.5.1140.

Santosa, M. H., Paramartha, A. A. G. Y., \& Absari, R. M. (2020). Indonesian English University Students ' Perceptions on Plagiarism in The Online World Era. Journal of ELT Research, 4(August 2019), 100114. https://doi.org/10.22236/JER.

Si, P. (2019). A Study of the Differences between EFL and ESL for English Classroom Teaching in China. 15(01), 32-35. https://doi.org/10.21013/jems.v15.n1 .p4.

Sukandi, S. S. (2019). Writing Thesis in The Field of English Education: How Difficult Is It For Indonesian EFL Students? English Language Teaching and Research Journal, 3(1), 55-72. https://doi.org/10.37147/eltrj.v3i1.60.

Wilkinson, D., \& Birmingham, P. (2003). Using Research Instruments (A Guide for Researchers). 